\title{
Learning activities using videos to strengthen intercultural competence in higher education students
}

Actividades de aprendizaje con vídeos para fortalecer la competencia intercultural de los estudiantes de educación superior

John Cano", Carmen Ricardo Barreto", Jorge Mizuno Haydar"', Humberto Llinas Solano"'-

Universidad del Norte

Recibido: 6 de junio de 2020-Aceptado: 11 de junio de 2021-Publicado: 1 de enero de 2022

Forma de citar este artículo en APA:

Cano, J., Ricardo-Barreto, C., Mizuno-Haydar, J., \& Llinas-Solano, H. (2022). Learning activities using videos to strengthen intercultural competence in higher education students. Revista Colombiana de Ciencias Sociales, 13(1), 133-150. https://doi.org/10.21501/22161201.3636

\section{Abstract}

The use of properly designed educational videos has proven effective in strengthening intercultural competence in higher education. In this article, we present the results of an investigation whose objective was to determine the characteristics of learning activities that use videos to promote the development of the intercul-

• Doctor en Educación de la Universidad de California, Santa Bárbara, Estados Unidos. Profesor Asistente de la Universidad del Norte, pertenece al grupo de Informática Educativa de la Universidad del Norte, Barranquilla-Colombia. Contacto: bjohn@uninorte.edu.co. https://orcid.org/0000-0002-0422-4621. Google Scholar: https://scholar.g0ogle.es/citations?user=0gHFOU MAAAAJ\&hl=es

“ Doctora en Educación, UNED-España. Profesora asociada del departamento de Educación de la Universidad del Norte, Barranquilla, Colombia. Pertenece al grupo de Informática Educativa de la Universidad del Norte. Contacto: cricardo@uninorte.edu.co. https://orcid.org/0000-0002-0474-685X Google Scholar: https://scholar.g0ogle.es/citations?user=C7I7Nd4AAAAJ\&hl=es

-.- Magister en Educación de la Universidad del Norte y la Universidad Javeriana, Colombia. Profesor Emérito de la Universidad del Norte, Barranquilla, Colombia. Contacto: jmizzuno@uninorte. edu.co. https://orcid.org/0000-0002-5083-3540 Google Scholar: https://scholar.google.com/citations?user=zAT8sL4AAAAJ\&hl=es

-.-' Doctor en Ciencias Naturales, Universidad de Mainz, Alemania. Profesor titular del Departamento de Matemáticas y Estadística e investigador del grupo de investigación de Matemáticas de la Universidad del Norte, Barranquilla-Colombia. Contacto: hllinas@uninorte.edu.co. https://orcid.org/0000-0002-2976-5109 Google Scholar: https://scholar.g0ogle.com/citations?user=U_6VOSAAAAJ\&hl=es 
tural competence of students of virtual courses. The study was carried out using a mixed approach in which quantitative and qualitative techniques were used for data collection and analysis. The results showed that the significant changes in students occurred when the activities were based on videos that presented different situational and real contexts, promoting cultural knowledge, critical reflection and, experiential analysis. The role of the teacher is paramount in the design of activities and in their role as facilitator and guiding them.

\section{Keywords}

Interculturality; Educational video; Students; Online education; Intercultural competence.

\section{Resumen}

El uso de vídeos educativos adecuadamente diseñados ha demostrado ser eficaz para fortalecer la competencia intercultural en la educación superior. En este artículo se presentan los resultados de una investigación cuyo objetivo fue determinar las características de las actividades de aprendizaje que utilizan videos para promover el desarrollo de la competencia intercultural de los estudiantes de cursos virtuales. El estudio se llevó a cabo mediante un enfoque mixto en el que se utilizaron técnicas cuantitativas y cualitativas para la recogida y el análisis de datos. Los resultados mostraron que los cambios significativos en los estudiantes se produjeron cuando las actividades se basaron en vídeos que presentaban diferentes contextos situacionales y reales, promoviendo el conocimiento cultural, la reflexión crítica y, el análisis experiencial. El papel del profesor es primordial en el diseño de las actividades y en su rol de facilitador y orientador de las mismas.

\section{Palabras clave}

Interculturalidad; Vídeo educativo; Estudiantes; Educación en línea; Competencia intercultural. 


\section{Introduction}

When interculturality is mentioned, reference is made to the encounters, interactions, dialogues and exchanges that occur between different cultures, bearing in mind the recognition of the diversity that exists in the world, with the aim to construct a society with equity and justice, not allowing the segregation or submission of cultural minorities by confronting racism, discrimination and inequality (Arroyo, 2016; Mato, 2008).

In Colombia, different spaces are presented for the encounter, exchange and dialogue between cultures, which emphasize the importance of designing and having formal educational proposals for diverse populations (Alban, 2005; MEN, 2009). Intercultural education seeks to promote human development, allowing for a teaching experience filled with respect, acceptance, appreciation for diversity, healthy coexistence and unity among cultures (Aguado, 2003; Arroyo \& McWilliam, 2002; Malik, 2003; Vilà Baños, 2008).

The use of educational videos constitutes a didactic strategy for the achievement of meaningful learning, allowing bringing real situations into the class and the generation of reflexive processes when guided by the intervention of teachers in the formative process (Díaz, 2009; García Matamoros, 2014; Chun, 2015).

The use of video as a pedagogical resource facilitates the teaching and learning process because it fosters concept construction in a more pleasant and funny way and, at the same time, presents contents in a more dynamic way due to the characteristics of its language and its capacity to stimulate the different sensorial channels that increase motivation and favors learning. In the same way, the video suggests behavior models using everyday language and highlighting a value at the expense of others (Machado, 2012; Machado \& Meirelles, 2018; Moran, 2002; Gomes Catunda de Vasconcelos \& Leão, 2009).

Studies, like the ones conducted by Chun (2015), and Aneas, and De Santos (2007) show evidence of the possibilities that video and telecollaboration offer to promote Intercultural Competence in higher education students, since it helps promoting cultural awareness of the participants and allows them to be aware of their attitudes when interacting with different cultures. Additionally, research findings by different scholars (Peláez-Cárdenas et. Al., 2013; Dubreil, 2002; García Matamoros, 2014) show that the use of video in learning activities helps promoting reflections, analysis and a deeper appreciation and knowledge about the students' own culture. Also, these studies reported that when students are encouraged to produce their own culturerelated videos, they can develop a better understanding of culture and different set of literaciese.g. writing skills and digital literacy. 
This article focuses on the probable changes produced in the development of students' intercultural competence when facing learning activities that use video to promote such competences. Besides, it also explores students' perceptions about the way this strategy contributes to the development and strengthening of their intercultural competence. This study shares a novel approach of the application of digital content to improve the effectiveness of intercultural competences learning. The findings can be potentially used as the basis for justifying future application of such techniques in higher educational contexts.

This paper presents firstly a theoretical review of both the activity characteristics that favor interculturality and the use of educational videos as a pedagogical strategy. Secondly, it describes the methodological approach. Finally, it describes the results as follows: first, the design of learning activities; second, results of pre- and post-tests (quantitative analysis); third, the analysis of students' perceptions (qualitative analysis); and some conclusions.

\section{Literature review}

Intercultural education is the way to develop intercultural competences in students, which allows for the existence of communication amongst diversity, favoring the recognition of one's own culture, cultural history, ethnicity and language, enabling the richness present in the worldview of others to be valued (Aguado, 2003; Malik, 2003; Vilà Baños, 2008).

Students' intercultural competence considers two basic sub-competences (Aguado, 2003): "intercultural effectiveness", and "understanding and respect for differences and diversity", defined as follows:

- Intercultural effectiveness: it implies the understanding of one's culture and that of other people, the capacity of identifying communicative patterns and behaviors that lead to discrimination, and the acquisition of skills to maintain effective intercultural relationships, that is, to listen to others, share and enjoy experiences with diverse people or groups.

- Understanding and respect for differences and diversity: refers to the ability to become aware of the diversity one possesses and identify other people and groups; being able to analyze one's own values regarding sexism, racism, stereotype, prejudice and discrimination, and understanding the stereotypes and the impact they have on behavior. 
Table 1.

Indicators of Intercultural Sub-Competences

\section{Intercultural Sub-Competences Indicators}

Indicator 1: Increase of the understanding of own culture.

Indicator 2: Awareness of the validity of worldviews different from one's own.

Indicator 3: Knowledge of characteristics and codes used in diverse cultures.

Intercultural effectiveness

Indicator 4: Identification of communicative guidelines and behaviors that lead to discrimination.

Indicator 5: Obtaining skills to maintain effective intercultural relationships.

Indicator 6: Demonstration of adaptability and confidence in addressing issues of inequality, prejudice and abuse of power.

Indicator 7: Raise awareness of the diversity that characterizes individuals and groups.

Understanding and respect for

Indicator 8: Analysis of personal values regarding racism, prejudice, stereotypes and

differences and diversity discrimination.

Indicator 9: Development and incorporation of the understanding of stereotypes and their impact on one's own behavior.

Based on Aguado (2003)

In order to promote the development of competences in virtual educational contexts, it is necessary to structure authentic activities and tasks online (Badia et al., 2001; Bozalek et al., 2013; Medina et al., 2010; et al., 2007). These activities and tasks favor the collective construction of knowledge, the communicative and intercultural reflection, the development of teamwork that facilitates exchanges and relationships between culturally diverse students, and the development of joint projects. They also promote the contrast between individual and collaborative cultural situations. These tasks have the guidance or virtual tutoring of the teacher characterized by a permanent interaction between teacher-student and student-student (Aneas \& De Santos, 2007; Cano et al., 2016; McCloskey, 2012; Paredes, 2011; Rodríguez Izquierdo, 2015).

Teachers can design digital educational resources, such as educational videos, to keep the attention and interest of students, increase motivation, and improve the learning experience. Likewise, learning activities using videos allow the construction of cultural knowledge, and the analysis and critical reflection, because of the perceptions and emotions aroused in students in relation to real situation shown on the videos. Videos can be also used to share previous experiences related to intercultural conflictive situations and analyzed together with learning process actors (Cruse, 2007; Dubreil, 2002; García, 2014; Mayer, 2001; Osuna, 2000; Peláez-Cárdenas et al., 2013; Quintero et al., 2019). 


\section{Methodology}

The study was carried out in a higher-education institution of the Colombian Caribbean Coast. Participants included 58 undergraduate students from different undergraduate programs in Engineering, Humanities, Education, Law, Administrative Sciences, and Architecture that took the virtual course "Intercultural Education" in 2017.

The research used the mixed approach, as it sought, through methodological complementarity, to observe, describe, analyze and verify the information found regarding a specific phenomenon in the research process (Creswell, 2014). Its design corresponded to a sequential explanatory design (Hernández et al., 2010). In a first phase, the quantitative data were collected and analyzed, while a second phase covered qualitative data; the former provided information for the collection of the latter; that is, for the analysis; both types of data were integrated for a better and deeper interpretation of the results.

For data collection, a self-perception survey of intercultural competences was used at the beginning and at the end of the Intercultural Education course, which consisted of 6 modules lasting sixteen weeks (an academic semester). Also, a documentary analysis of the tasks related to the learning activities that used the video as pedagogic mediation was carried out.

The survey consisted of 23 questions, the first 17 oriented to the sub-competence "Intercultural effectiveness" and the last 6 , to the sub-competence "Understanding and respect for differences and diversity", with an evaluation scale: "Nothing" (1), "A little" (2), "Fairly" (3) and "A lot" (4).

After obtaining the data using the different qualitative (documentary analysis) and quantitative (survey) techniques, the triangulation was carried out, considering the Sub-Competences Indicators based on Aguado (2003) (Table 1).

Regarding the analysis of the quantitative data, inferential statistics tools have been applied to compare results obtained in the pre-test to the ones of the post-test, in order to identify the significant differences between them. To do this, Statgraphics Centurion XVII and SPSS 24 statistical packages have been used. 


\title{
Results
}

\section{Design of Learning}

The "Intercultural Education" course expects students to

\begin{abstract}
understand the theoretical-conceptual principles of intercultural education, the different visions, proposals and models that make possible an intercultural education articulated to the social context and the demands that the globalized world presents, all in a multi-cultural and intercultural learning environment. (Ricardo, 2014, p. 2)
\end{abstract}

Likewise, the course aims at promoting the development of Intercultural Competence and its two sub-competences "Intercultural effectiveness" and "Understanding and respect for differences and diversity" (Aguado, 2003).

At the methodological level, the course integrates diverse techniques, methods and procedures through teacher orientation in a learning environment mediated by Information and Communication Technologies (ICT), promoting autonomous learning and collaborative learning to favor the rapprochement and dialogue between diverse cultures.

In the course, three learning activities were carried out, in which educational videos were used and students were encouraged to use spaces for reflection, analysis, and discussion about intercultural experiences in order to favor the development of their intercultural competence.

The learning activities are described as follows:

- Learning activity "Identifying Stereotypes": This activity is designed taking into account the indicators 7,8 y 9 (Table 1) in order to develop the Understanding and respect for differences and diversity Sub-Competence. In the activity, students should watch ten short videos designed by the teacher, which show situations that highlight Colombian culture stereotypes and prejudices (Ricardo, 2014). The videos show jokes and experiences lived by people representing Colombian different cultural groups. After watching videos, students should analyze and reflect on positive and negative emotional reactions to other cultural groups and share them with their peers in a discussion forum. 
- Learning Activity "Maintaining Effective Intercultural Relationships": To design this activity it was considered the sub-competences Indicators 3, 4, 5, and 6 as a guideline to promote the Intercultural effectiveness sub-competences. In this learning activity, students are expected to develop communicative skills that enable them to maintain effective relationships with the cultural diversity of the world (Ricardo, 2014).

Students should make a video with easily accessible resources (digital camera, mobile phones, tablets, web cam or any device they have available for video recording). The video to be produced consists of conducting an interview with a culturally different person, in which questions must be asked that allow knowing key aspects of the culture of the interviewee, such as family experience, complex or difficult situations experienced, customs, way of relating with other people, among others.

In the pre-production step of the video-interview, students have to identify a culturally different individual, establish strategies to approach him/her in order to obtain his/her consent to share experiences related to his/her culture, through an interview that will be video-recorded.

Once the video is recorded, students share it with their peers in a social video platform or network (e.g. Vimeo or YouTube). Then, they participate in a discussion forum, sending and sharing their reflection on the work done, highlighting the contributions and/or changes that this activity generated in their intercultural competence. Likewise, it is expected that they will review and comment on the contributions and shared experiences of their peers.

- Learning Activity "Creating Videos in the MAPUKA ${ }^{1}$ Uninorte Museum": This learning activity promotes two Intercultural Sub-competences, that is Intercultural effectiveness and Understanding and respect for differences and diversity having in mind indicators $1,2,3$, and 7. To carry out this activity, students should visit the MAPUKA Museum of the Universidad del Norte. After that, they create short videos (with mobile devices) by using information from the museum. In the videos, students show the most representative cultural characteristics of the Colombian Indigenous Caribbean coast population (Ricardo, 2014). The process consists of three moments: First moment: Theoretical approach. Students review literature about the sub-cultures of the Colombian Caribbean region, and produce a Power Point presentation with the collected information. Second moment: Guided visit to MAPUKA museum with the aim of elaborate a video about one of the indigenous groups shown in it. Third Moment: Share the video with peers and reflect about the activity.

${ }^{1}$ MAPUKA: Anthropological and archeological museum of the Universidad del Norte, a higher education institution in Barranquilla, Colombia. 


\section{Changes in Students' Intercultural Competences (Qualitative Analysis)}

Firstly, this section shows the results of the level of development of global competence (intercultural competence) and its two sub competences.

To analyze data, independence and uniformity tests (Llinás, 2014) were developed by using a 5\% significance level. The Statgraphics Centurion XVII and SPSS 24 statistical packages have been used to carry out the analysis. Table 2 shows results for Chi-square test value, its respective freedom grade, and p-value of each sub-competence and its indicators.

As it is shown in Table 2, there are significant differences between the pre-test and the post-test regarding indicators 1, 7 and 9. It is worthwhile to highlight results of indicator 5 with a p-value close to 0.05 . This seems to indicate that, although there is no a significant difference, there exists a positive effect of the pedagogical intervention.

Table 2

Summary of the comparative tests (pre-post) of the results of indicators of sub-competences

\begin{tabular}{|c|c|c|c|c|}
\hline Subcompetences & Indicator & $\begin{array}{l}\text { Chi-square } \\
\text { value }\end{array}$ & $\begin{array}{l}\text { Freedom } \\
\text { grade }\end{array}$ & P-value \\
\hline \multirow{6}{*}{ Sub-competence: Intercultural effectiveness } & Indicator 1 & 6,71 & 2 & 0,035 \\
\hline & Indicator 2 & 3,26 & 2 & 0,196 \\
\hline & Indicator 3 & 5,53 & 6 & 0,478 \\
\hline & Indicator 4 & 7,28 & 4 & 0,122 \\
\hline & Indicator 5 & 11,51 & 6 & 0,074 \\
\hline & Indicator 6 & 0,40 & 1 & 0,525 \\
\hline \multirow{3}{*}{$\begin{array}{l}\text { Sub-competence: Understanding and respect } \\
\text { for differences and diversity }\end{array}$} & Indicator 7 & 41,21 & 9 & 0,000 \\
\hline & Indicator 8 & 1,64 & 1 & 0,200 \\
\hline & Indicator 9 & 19,14 & 6 & 0,004 \\
\hline
\end{tabular}

Source: self made.

Table 3 shows the differences between the global results of the pre-test and the post-test regarding the sub-competences and the intercultural competence. Concerning the global intercultural competence, there is no evidence of significant differences. However, with respect to the sub-competence "Understanding and respect for differences and diversity", there is a significant difference that indicates a positive effect on the students' development of such subcompetence. 
Table 3

Summary of the comparative tests (pre-post) of the global results of intercultural competences

\begin{tabular}{lccc}
\multicolumn{1}{c}{ Intercultural Competence } & Chi-square value & Freedom grade & P-value \\
$\begin{array}{l}\text { Sub-competence: Intercultural } \\
\text { effectiveness }\end{array}$ & 4,97 & 2 & 0,083 \\
\hline $\begin{array}{l}\text { Sub-competence: Understanding and } \\
\begin{array}{l}\text { respect for differences and diversity } \\
\text { competence }\end{array}\end{array}$ & 26,37 & 4 & $\mathbf{0 , 0 0 0}$ \\
\hline \begin{tabular}{l} 
Intercultural Competence \\
\hline
\end{tabular} & 4,52 & Source: self made.
\end{tabular}

These results allow inferring the contribution of implemented activities to the development of the sub-competences. So, activity 1 helped students to raise awareness of the diversity that characterizes individuals and groups, and to develop and incorporate the understanding of stereotypes and their impact on one's own behavior. On the other hand, activity 3 made possible to increase the understanding of own culture and raise awareness of the diversity that characterizes individuals and groups.

Although activity 2 has no favorable results regarding the development of intercultural competence, it is convenient to highlight the change produced in participants by obtaining skills to maintain effective intercultural relationships.

\section{Students Perceptions about their Intercultural Competences Strengthening (Qualitative Analysis)}

For the documentary analysis of the learning activities, students' interventions during the course activities were collected and analyzed taking as support the N-Vivo Qualitative Analysis Software.

\section{Intercultural effectiveness Sub-Competence}

In the "Identifying stereotypes" activity, students can emphasize the importance of maintaining openness by interacting and approaching other cultures, as well as taking attitudes and values that demonstrate respect for diversity, giving validity to the cultural worldviews that differ from our own. In this way, some students expressed the importance of recognizing our own limits and 
weaknesses in our abilities for communication and intercultural dialogue. They claim that it is necessary to reflect on how we act and approach other cultures, this being the first step to improve and generate a genuine and enriching interaction.

Likewise, in the activity "Maintaining Effective Intercultural Relationships", it was demonstrated that students identify barriers that limit open intercultural dialogue and the need to be aware of and recognize limits when interacting with people who have worldviews that are different from theirs, maintaining a climate of respect and acceptance in the face of cultural diversity.

In the "Mapuka Video" activity, the students emphasized the importance of knowing and studying the cultural legacy that is often not considered in the formative processes. Likewise, they value positively the development of the learning activity as it helps them improve their communicative abilities with diverse cultures.

\section{Respect for Differences and Diversity Sub-Competence}

In the "Mapuka Video" and "Identifying Stereotypes" activities, students expressed the importance of being aware of the existence and validity of different cultural groups in the world. They highlight the need for everyone to learn to be more respectful, tolerant and warm when interacting with others, leaving aside any preconceived ideas, prejudices, or any kind of discriminatory manifestation towards any human being.

Some students analyzed the values associated with prejudice, discrimination, stereotypes, racism, abuse of power, among others, identifying and establishing a relationship between these and how they affect intercultural dialogue, where the fundamental basis for healthy coexistence is respect and tolerance:

\section{Triangulation}

Intercultural Effectiveness Sub-Competence Summary: The quantitative and qualitative results coincide in the positive transformation that occurs in the "intercultural effectiveness" sub competence of students after participating in the training process. Learning activities contributed to the preparation of the participants so that they could understand and value their culture, and that of others, and recognize how their attitudes and behaviors in interacting positively or negatively with culturally diverse people affect the relationship. 
Understanding and Respect for Differences and Diversity Sub Competence Summary: This sub competence, "Understanding and respect for differences and diversity", also reflects a favorable development in the participants, after attending the course of virtual training and dealing with learning activities that favor these sub competences. That is, there is a coincidence in the results obtained through quantitative and qualitative instruments. Findings show that participants gained a greater awareness of the diversity that characterizes individuals and groups; of their values against racism, prejudices, stereotypes or any discriminatory attitude; and of how stereotypes affect their behavior.

\section{Discussion}

Taking into account the research objective, results are discussed regarding the contribution of each activity to the development of intercultural competence.

\section{Activity 1}

Findings makes evident that this activity promotes the development of indicators associated to the understanding and respect for differences and diversity through recognizing stereotypes and reflecting about emotional reaction, both positive and negative. It is likely due to the funny characteristics of video used in the activity (regional jokes about cultural stereotypes). When using videos as a pedagogical resource, teachers are free to choose the more pertinent contents in order to achieve their formative goals. In this case, the jokes used show actual models of behavior and use everyday languages, features that make easier for students to reflect about the values promoted by the intercultural education (Machado, 2012; Machado \& Meirelles, 2018; Moran, 2002; Gomes Catunda de Vasconcelos \& Carneiro Leão, 2009).

\section{Activity 2}

There is no evidence of significant changes in the indicators related to this activity; however, findings in indicator 5 make evident a positive effect of the pedagogical intervention because there are signals of the development of skills to deal with effective intercultural relationships. Overall results seem to indicate the activity implies a metacognitive process to which students are not probably accustomed and that is more difficult in virtual environments. In the preparation step of the 
video-interview, the student needed to reflect about the cultural characteristics of the interviewee and to define strategies to approach him/her in a culturally effective way. This may explain the results of the indicator 5 (Chun, 2015; Díaz, 2009; García Matamoros, 2014).

\section{Activity 3}

This activity points at developing four indicators. Two of them shows significant results (indicators 1 and 7) and are closely linked because Indicator 1 aims at the understanding of own culture and the seven one, at the awareness of diversity that characterizes individuals and groups. In order to be aware of the diversity of other, one has to be able of understanding, at first, own culture. As the own culture is understood and diversity in other people is recognized, the intercultural competence is achieved (Aguado, 2003; Malik, 2003; Vilà Baños, 2008).

To sum up, indicator 7 shows the highest statistically significant results. It is promoted by activities 1 and 3 . Indicator 9, promoted by activity 1 , shows the second statistically significant results. The third higher result corresponds to indicator 1 , closely related to indicator 7 , and promoted by activity 3 . It is also worthwhile to highlight that the activities carried out are characterized by being authentic because they are framed in the participants' multicultural context. At the same time, they favor interaction, collective learning construction, and communicative and intercultural reflection (Aneas \& De Santos, 2007; Cano, Ricardo \& Del Pozo, 2016; McCloskey, 2012; Paredes, 2011; Rodríguez Izquierdo, 2015; Woo, Herrington, Agostinho \& Reeves, 2007).

\section{Conclusions}

Based on the results obtained in this research and the process of designing learning activities that used the educational video as the main mediating tool, we can highlight several aspects that are important to favor the development of intercultural competence of students in higher education in virtual contexts.

One of the first aspects to highlight relates to the design of learning activities that respond to the same pedagogical and didactic approach. In this project, the quantitative and qualitative results allow for the conclusion that the activities contributed to the development of the "intercultural effectiveness" and "understanding and respect for differences and diversity" sub competences. This was possible because they involved the communicative and intercultural reflection of 
students, the analysis of situations in real contexts, the collective construction of knowledge, and the permanent linkage of students with their formative process and that of their peers (Badia et al., 2001; Bozalek et al., 2013; Medina et al., 2010; Ricardo \& Mizuno, 2016).

Likewise, the use of video was appropriately incorporated into the design of learning activities, in such a way that it was constituted as a means for the generation of cultural knowledge. Critical reflection and analysis based on experiences and feelings emerged when observing the video materials. These show different situational and real contexts and were either provided by the teacher or produced by the students themselves (Cruse, 2007; Dubreil, 2002; García, 2014; Mayer, 2001; Osuna, 2000; Peláez-Cárdenas et al., 2013).

One problem arising from results is that trying to promote several indicators with one activity, favor and privilege some indicator making the others unknown.

Recommendations to be considered in similar projects are as follows:

- Teachers should be very critical when using educational videos, particularly when these are taken from external banks (videos designed by other authors). In this case, they should bear in mind that the topic of the video is relevant to the context of their students, being possible to generate spaces for reflection and analysis that strengthen their intercultural competence.

- If teachers want to produce their own educational videos, they should analyze and study real and/or contextualized situations of the student they teach.

- When designing a learning activity, teachers should establish in a clear and specific way the guidelines that should be followed for the development of the tasks corresponding to each activity.

- It is advisable to link activities to just one or two indicators in such a way the strengthening and achievement of learning objectives result easier.

\section{Conflict of interest}

The authors declare that there is no conflict of interest with any commercial institution or association. 


\section{References}

Aguado, T. (2003). Pedagogía Intercultural. Mc Graw Hill.

Aneas, A., \& De Santos, F. J. (2007). Formación intercultural para profesionales: Medios de comunicación. Ediciones Fundación Atman.

Arroyo, A. (2016). Pedagogías decoloniales y la interculturalidad: perspectivas situadas. In M. Di Caudo, D. Llanos \& C. Ospina (Coords.), Interculturalidad y Educación Desde el Sur: Contextos, experiencias y voces (pp. 47-66). Editorial Universitaria Abya-Yala.

Arroyo, R., \& McWilliam, N. (2002). La escuela y el currículo intercultural. In A. Medina, \& F. Salvador (Coords.), Didáctica General (pp. 407-435). Pearson Educación.

Badia, A., Barberà, E., \& Mominó, J. M. (2001). La incógnita de la educación a distancia. ICE UB/ Horsori.

Bozalek, V., Gachago, D., Alexander, L., Watters, K., Wood, D., Ivala, E., \& Herrington, J. (2013). The use of emerging technologies for authentic learning: A South African study in higher education. British Journal of Educational Technology, 44(4), 629- 638. https://doi. org/10.1111/bjet.12046

Cano, J., Ricardo, C., \& Del Pozo, F. (2016). Competencia intercultural de estudiantado de educación superior: Un estudio en la Universidad del Norte (Barranquilla. Colombia). Revista Encuentros, 14(2), 159-174.

Chun, D. M. (2015). Language and culture learning in higher education via telecollaboration. Pedagogies: An International Journal, 10(1), 5-21. https://doi.org/10.1080/155448 0X.2014.999775

Creswell, J. W. (2014). Research design: qualitative, quantitative, and mixed methods approaches (4th ed). SAGE Publications.

Cruse, E. (2007). Using educational video in the classroom: Theory, research and practice. Library Video Company.

Díaz, R. (2009). El video en el ciberespacio: usos y lenguaje. Revista Comunicar, XVII (33), 6371. https://eprints.ucm.es/id/eprint/9492/ 
Dubreil, S. (2002). An empirical investigation on using video and the Internet to teach culture in the intermediate-level foreign language classroom[Doctoral dissertation, Emory University].

García, C. (2014). The combination of task-based learning and video to develop secondary students' ICC [Tesis de Maestría, Universidad de la Rioja] at http://biblioteca.unirioja.es/ tfe_e/TFE000604.pdf

García Matamoros, M. A. (2014). Uso Instruccional del video didáctico. Revista de Investigación, 38(81), 43-67.

Gomes Catunda de Vasconcelos, F., \& Carneiro Leão, M. (2009). O vídeo como recurso didático para ensino de ciências: uma categorização inicial. In: IX Jornada de Ensino, Pesquisa e Extensão, out, 2009, Recife, PE. Anais eletrônicos. Universidade Federal Rural de Pernambuco, Recife.http://www.eventosufrpe.com.br/jepex2009/cd/resumos/R0315-1.pdf

Hernández, R., Fernández, C. \& Baptista, P. (2010). Metodología de Investigación (5ta ed.). McGraw Hill.

Llinás, H. (2014). Introducción a la estadística matemática. Editorial universidad del NorteECOE ediciones.

Machado, M. H. (2012). Uso do vídeo como ferramenta no ensino de genética [ Dissertação Mestrado, Volta Redonda].

Machado, M. H., \& Meirelles, R. M. S. (2018). Uso do vídeo no ensino de biologia como estratégia para discussão e abordagens de temas tecnológicos. Cadernos UniFOA, 4(1 Esp.), 79. https://revistas.unifoa.edu.br/cadernos/article/view/2608

Malik, B. (2003). Desarrollo de competencias interculturales. Material para un curso de doctorado en orientación. https://docplayer.es/11041007-Desarrollo-de-competencias-interculturales-en-orientacion-dra-beatriz-malik-lievano.html

Mato, D. (Coord.) (2008). Diversidad cultural e intercultural en educación superior. Experiencias en América Latina. IESALC-UNESCO. https://biblio.flacsoandes.edu.ec/libros/112589opac

Mayer, R. E. (2001). Multimedia learning. Cambridge University Press. 
McCloskey, E. (2012). Docentes globales: Un modelo conceptual para el desarrollo de la competencia intercultural on-line. Comunicar, XIX(38), 41-49. https://doi.org/10.3916/C382012-02-04

Medina, A., Domínguez M. C., \& López, E. (2010). Tendiendo puentes hacia la interculturalidad: las nuevas escuelas y docentes. In F. Ramos (Coord.), Lancando Pontes para a Interculturalidade (pp. 19-50). Junta de Andalucía-Consejería de Innovación, Ciencia y Empresa, Grupo de Investigación D.E.Di.C.A (Desarrollo Educativo de las Didácticas en la Comunidad Andaluza).

Moran, J. (2002). Desafios da televisão e do vídeo à escola. Texto de apoio ao programa Salto para o Futuro da TV Escola no módulo TV na Escola e os Desafios de Hoje. http://www. tvebrasil.com.br/salto/boletins2002/tedh/tedhtxt2b.htm2>

Osuna, M. (2000). Promoting foreign culture acquisition via the Internet in a sociocultural context. Journal of Educational Computing Research, 22(3), 323-345. https://doi. org/10.2190/9FXU-DH7Q-LCQ3-E45J

Paredes, J. (2011). Introducción de las TIC en la enseñanza secundaria. En A. Medina, A. Herrán \& C. Sánchez (Coords.), Formación pedagógica y práctica del profesorado (pp. 153-180). Editorial Universitaria Ramón Areces.

Peláez-Cárdenas, A., Villa, V. Zapata, S. Ricardo, C., \& Manotas, E. (2013). Making of educational videos, an experience to learn among all. A closer look into the use of audiovisual media for a pedagogical development. Revista $Q, 7(14), 17$. Available at https://repository. upb.edu.co/handle/20.500.11912/6813

Quintero Solano, A., Riveira Zuleta, C., Mosquera Arteta, A., Cano Barrios, J., \& Manotas Salcedo, E. (2019). Eficacia Intercultural y uso de videos: caracterización de la producción audiovisual de estudiantes de básica secundaria del Caribe Colombiano. Revista Colombiana de Ciencias Sociales, 10(1). https://doi.org/10.21501/22161201.3063

Ricardo, C. (2014). Parcelación de la asignatura "Educación Intercultural” del departamento de Educación de la Universidad del Norte [Documento Interno]. Universidad del Norte.

Ricardo, C. \& Mizuno, J. (2016). Pedagogical Intercultural Practice of Teachers in Virtual Enviroments. Turkish Online Journal of Distance Education, 17(4). https://doi.org/10.17718/ tojde.24492Rodríguez Izquierdo, R. (2015). Las TIC como ecosistema para la construcción de la competencia intercultural. Revista Profesorado, 19(1), 309-329. https://recyt. fecyt.es/index.php/profesorado/article/view/41043 
Vilà Baños, R (2008). La competencia comunicativa intercultural. Un estudio en el primer ciclo de la Educación Secundaria Obligatoria. Ministerio de Educación, Política Social y Deporte, CIDE: Centro de Investigación y Documentación Educativa. Colección investigación.

Woo, Y., Herrington, J. Agostinho, S., \& Reeves, T.C. (2007). Implementing Authentic Tasks in Web-Based Learning Environments. The instructor's inclusion of authentic activities improves the quality of student interaction and learning in online classrooms. Educause Quartely, (3), 36-43. https://er.educause.edu/-/media/files/article-downloads/eqm0735. pdf 